Running head: HOW AUTHENTIC LEADERSHIP PROMOTES INDIVIDUAL CREATIVITY

How authentic leadership promotes individual creativity:

The mediating role of affective commitment

Neuza Ribeiro, ${ }^{a *}$ Ana Patrícia Duarte, ${ }^{b}$ Rita Filipe, ${ }^{c}$ and Rui Torres de Oliveira ${ }^{d}$

${ }^{a}$ Escola Superior de Tecnologia e Gestão, Instituto Politécnico de Leiria, Campus 2, Morro do

Lena-Alto Vieiro, Apartado 4163, 2411-901 Leiria, Portugal; neuza.ribeiro@ipleiria.pt

bInstituto Universitário de Lisboa (ISCTE-IUL), Business Research Unit (BRU-IUL), Av.

Forças Armadas, 1649-026 Lisbon, Portugal; patricia.duarte@iscte-iul.pt

${ }^{c}$ Escola Superior de Tecnologia e Gestão, Instituto Politécnico de Leiria, Campus 2, Morro do Lena-Alto Vieiro, Apartado 4163, 2411-901 Leiria, Portugal; rita.filipe@live.com.pt

${ }^{\mathrm{d}}$ University of Queensland, Brisbane St Lucia, QLD 4072, Australia;

r.oliveira@business.uq.edu.au

*Corresponding author

To cite this document:

Ribeiro, N., Duarte, A. P., Filipe, R., \& Torres de Oliveira, R. (2019). How Authentic Leadership

Promotes Individual Creativity: The Mediating Role of Affective Commitment. Journal of

Leadership \& Organizational Studies. https://doi.org/10.1177/1548051819842796 


\title{
How authentic leadership promotes employees' individual creativity: \\ The mediating role of affective commitment
}

\begin{abstract}
This study sought to provide a more comprehensive understanding of how authentic leadership can affect employees' individual creativity through affective commitment's mediating role. The sample included 177 leader-follower dyads from 26 private, small and medium-sized enterprises. Followers reported their levels of affective commitment and perceptions of authentic leadership, and leaders assessed each follower's level of creativity. The results show that authentic leadership has a positive impact on affective commitment and creativity. Moreover, affective commitment fully mediates the relationship between perceived authentic leadership and individual creativity. Organizations can thus increase employees' affective commitment and creativity by encouraging their managers to adopt more authentic leadership styles. Additional studies with larger samples are needed to determine more clearly not only authentic leadership's influence on individual creativity but also other psychosocial and personal variables' effects on that relationship.
\end{abstract}

Keywords: authentic leadership, affective commitment, creativity, leader-follower dyads, mediation 


\section{Introduction}

The most recent economic crisis at the end of the previous decade included a large number of corporate scandals, failures in the banking industry, and the ethical and financial collapse of various high-profile organizations around the world. These major scandals have increased researchers' interest in studying more positive forms of organizational leadership that can restore confidence in different levels of governance and promote more positive attitudes and behaviors in the workplace (Brown, Treviño, \& Harrison, 2005; George, 2003). This has magnified the calls for leaders who act with responsibility, do not hide information or deceive followers but, unlike this, lead with authenticity and integrity.

This demand for authentic and more accountable leaders has encouraged the development of theories based on leaders' moral character such as authentic leadership (AL). According to Walumbwa, Avolio, Gardner, Wernsing, and Peterson (2008, p. 94), AL can be defined as 'a pattern of leader behavior that draws upon and promotes both positive psychological capacities and a positive ethical climate, to foster greater self-awareness, an internalized moral perspective, balanced processing of information, and relational transparency on the part of leaders working with followers, fostering positive self-development'.

AL has thus attracted wide attention in recent years (e.g., Avolio, Wernsing, \& Gardner, 2018; Banks, McCauley, Gardner, \& Guler, 2016; Černe, Jaklič, \& Škerlavaj, 2013; Hsieh \& Wang, 2015; Leroy, Palansky, \& Simons, 2012; Ribeiro, Gomes, \& Kurian, 2018; Semedo, Coelho, \& Ribeiro, 2016, 2017). Researchers believe that AL influences employees' positive attitudes and behaviors (Avolio \& Gardner, 2005), such as organizational citizenship behavior, organizational commitment, and work engagement (Walumbwa et al., 2008). For example, Avolio, Gardner, Walumbwa, Luthans, and May (2004) argue that authentic leaders can improve followers' work attitudes, such as organizational commitment and job satisfaction, which, in turn, lead to higher levels of job performance. The current research followed the same 
line of investigation, examining the impacts of perceptions of AL on employees' creativity, both directly and through the mediation of affective commitment.

Thus far, empirical evidence is still scarce on AL's outcomes (e.g., creativity) and, in particular, on the mediating role of some relevant variables (e.g., affective commitment). Researchers have previously tested the role of organizational commitment as a mediating variable affecting relationships between leadership behavior and employee job satisfaction and/or performance (Youssef, 2000). Moreover, researchers have tested the effect of AL on affective commitment (Ribeiro et al., 2018; Semedo et al., 2016) and creativity (Rego, Sousa, Marques, \& Cunha, 2012, 2014). However, no study in the literature reviewed for the present study has specifically examined the role of affective commitment as a variable mediating the relationship between $\mathrm{AL}$ and creativity - even though this organizational commitment component is connected with the most positive outcomes. Therefore, a major purpose of this study is to build and test theory that addresses the relationship between AL and creativity, considering an important intervening variable - affective commitment.

Hence, the present study sought to fill this research gap by demonstrating that AL can be very relevant in terms of encouraging employees' positive attitudes and behaviors, especially affective commitment and creativity. Organizations currently need creative and committed employees to survive and prosper facing these turbulent, challenging times. Scholars have demonstrated that AL increases employee's organizational citizenship behaviors (Joo \& Jo, 2017) and their engagement (Hsieh \& Wang, 2015), and it is also possible that it helps sustain an environment where positive attachments to the organization can form, such as through affective commitment. These specific relationships may provide insight into why AL is so crucial to maintaining a thriving, innovative, and ultimately, creative employee workforce. According to some scholars, the "mechanism in which leadership shapes the implementation of creative ideas has not been identified in enough detail" (Alzghoul, Elrehail, Emeagwali, \& 
AlShboul, 2018, p. 593). Therefore, these research variables can be considered worthy of research attention.

Thus, this study responds to calls in the literature for more empirical research examining how AL influences employee outcomes, expanding AL theory's nomological network, and assessing this concept's validity and stability across culturally diverse samples (Arda, Aslan, \& Alpkan, 2016; Avolio \& Mhatre, 2012; Gardner, Cogliser, Davis, \& Dickens, 2011; Hsieh \& Wang, 2015; Leroy et al., 2012; Rego, Vitória, Magalhães, Ribeiro, \& Cunha, 2013; Walumbwa et al., 2008).

In addition, although some previous studies have found significant relationships between the aforementioned variables (e.g., Banks et al., 2016; Černe et al., 2013; Leroy et al., 2012; Rego et al., 2013; Semedo et al., 2016), the incorporation of these relationships in a unique model constitutes an extension of prior work which helps explaining the process of how AL facilitates creativity. Compared with prior work, this study provides a more rigorous empirical methodology, including collecting data via a double-source method (i.e., leaderfollower dyads) to minimize the risk of common-method variance.

By examining affective commitment as a mediating mechanism in the relationship between AL and creativity, this research's results provide valuable insights that contribute to advancing not only AL theory but also the literature on affective commitment and individual creativity. This research's findings could prove beneficial to managers and organizations because the results show the extent to which authentic leaders can play a decisive role in creating specific attitudinal and behavioral responses in their followers.

\section{Research Background and Hypothesis Development}

$A L$

AL is a leadership theory that has attracted widespread attention among researchers. 
Although this theory has an already relatively well established body of research, various areas remain unexplored. AL is based on leaders' moral character, integrity, and consistency between principles, words, and actions. According to Walumbwa et al. (2008), AL is a pattern in leadership behavior that promotes positive psychological outcomes, such as an ethical climate, higher self-awareness, and an internalized moral perspective. These subsequently increase the balanced information treatment and the levels of transparency and relational work between leaders and followers, in that way promoting to the positive self-development of followers (Semedo et al., 2017).

Previously gathered theoretical and empirical evidence (Avolio, 2005; Avolio \& Gardner, 2005; Avolio et al., 2004; Gardner et al., 2005; Shamir \& Eilam, 2005; Walumbwa et al., 2008) suggests that the AL construct includes four dimensions:

(1) Self-awareness represents how well leaders understand their strengths, weaknesses, values, beliefs, and emotions, as well as how they impact other individuals.

(2) Balanced processing of information refers to how much leaders objectively analyze all relevant data before making decisions and solicit views that challenge their own positions.

(3) An internalized moral perspective represents how consistently leaders are guided by moral values and standards — versus team, organizational, or societal pressures—and their behaviors and decisions are congruent with internalized values.

(4) Relational transparency refers to how well leaders openly share information and present their authentic selves and sincere feelings, emotions, and thoughts to followers.

Prior studies have also proposed that a core AL construct can be extracted from the relationships among the four components (Gardner et al., 2005; Kernis \& Goldman, 2005; Rego et al., 2012; Rego et al., 2013; Walumbwa et al., 2008).

Previous research has found that AL enhances employees' positive attitudes and 
behaviors (Avolio \& Gardner, 2005; George, 2003; Ilies, Morgenson, \& Nahrgang, 2005) and consequently their organization's performance (Alshammari, Almutairi, \& Thuwaini, 2015; Avolio \& Mhatre, 2012; Walumbwa et al., 2008). Despite some overlap detected between AL and other leadership theories, AL has unique components, namely, self-awareness, balanced processing of information, internalized moral perspective, and relational transparency. These are quite important as they encourage employees' positive attitudes and behaviors (i.e., affective commitment and creativity). For example, by adopting an internalized moral perspective, authentic leaders promote honesty and integrity and discourage unethical behaviors within their organizations.

By being self-aware and relationally transparent and adopting balanced processing of information, authentic leaders also promote positive interpersonal relationships and trust among their followers (Avolio et al., 2004; Walumbwa et al., 2011). Thus, when leaders are authentic, they create a climate of authenticity and transparency in which employees can grow and fulfill their potential. A potential consequence of this is that employees develop an emotional attachment to their organization and greater creativity at work.

Some researchers have reported that correlations between AL and transformational and ethical leadership are not high enough to indicate that these concepts duplicate each other (Baron, 2016). Other studies have found incremental validity for AL theory beyond that for ethical and transformational leadership (Walumbwa et al., 2008). Avolio and Gardner (2005) also found several differences between AL theory and transformational, charismatic, servant, and spiritual leadership theories. In summary, although some overlap exists, AL has unique components, and researchers have posited that it is a root construct (Avolio \& Gardner, 2005) underlying other positive forms of leadership and their development (Avolio \& Mhatre, 2012; Nazari \& Emani, 2012). 


\section{AL and affective commitment}

According to Allen and Meyer (1990, 1996), organizational commitment can be characterized by three distinct mindsets. These are a desire to remain with an organization (i.e., affective commitment), a felt obligation to remain in the organization (i.e., normative commitment), and the perceived cost of leaving (i.e., continuance commitment). The literature indicates that, out of these three components, affective commitment—defined as employees' positive emotional attachment and identification with their organization (Allen and Meyer, 1990) — has more desirable outcomes for organizations (Meyer, Stanley, Herscovitch, \& Topolnytsky, 2002). Thus, organizations need to develop their employees' emotional attachment (Meyer and Herscovitch, 2001).

Researchers have previously sought to determine the antecedents of affective commitment (Allen \& Meyer, 1996; Meyer et al., 2002; Rego et al., 2013; Semedo et al., 2016). Various authors (e.g., Gardner et al., 2005; Kernis, 2003) have argued that authentic leaders' behavior conveys principles and values that promote the achievement and maintenance of open, genuine relationships. These scholars report that, the stronger leaders' authenticity is - as perceived by employees - the stronger the emotional bonds that ties the latter to their organization.

Authentic leaders thus create higher quality exchanges with employees, and employees reciprocate by being more affectively committed (Paillé, 2009). AL has been shown to drive employees' affective commitment through trust in and identification with their leaders (Walumbwa et al., 2008). For example, when employees work in a climate of trust, they develop pride in belonging to their organization and experience positive affect, that is, they develop higher affective commitment (Paillé, 2009; Rego et al., 2013). More specifically, by being relationally transparent, behaving honestly, and adopting balanced processing of information, authentic leaders develop greater affective attachment among their followers in the workplace. 
Peus, Wesche, Streicher, Braun, and Frey (2012) also supported the direct effect of AL on affective commitment. Both transformational and ethical leadership have also been confirmed to have a positive relationship with affective commitment (Allen \& Meyer, 1996; Alshammari et al., 2015; Bass \& Riggio, 2006; Meyer et al., 2002; Podsakoff, Mackenzie, \& Bommer,1996; Rafferty \& Griffin, 2004; Yucel, McMillan, \& Richard, 2014).

In general, employees are much more emotionally committed to performing their tasks well and focus more closely on achieving organizational objectives if they perceive their leaders as authentic (Darvish \& Rezaei, 2011; Leroy et al., 2012). In other words, AL is positively related to employees' emotional attachment to their organization (Avolio et al., 2004; Delić et al., 2017; Javaid, Luqman, Amir, \& Umair, 2015; Leroy et al., 2012; Rego et al., 2013; Semedo et al., 2016). This theoretical and empirical evidence supported the formulation of the following hypothesis for the present study:

H1: Employees' perceptions of AL are positively related to their affective commitment.

\section{AL and creativity}

Employee creativity is the process of generating, promoting, and implementing novel and useful ideas or solutions concerning products, services, and processes (Amabile, 1988; George \& Zhou, 2007; Shalley, Zhou, \& Oldham, 2004; Zhou, 2003; Zhou \& Shalley, 2003). This process involves risks, conflicts, difficulties, failures, and ethical dilemmas (Tu \& Lu, 2013). A positive, comfortable work environment inspires employees to be more creative, so leaders must encourage and develop a supportive work climate and positive, fair, and transparent interactions (Madjar, Oldham, \& Pratt, 2002; Muceldili, Turan, \& Erdil, 2013). Subsequently, subordinates feel free to experiment their ideas even when there is room for failure (Alzghoul, Elrehail \& Emeagwali, 2018).

Prior research has found that supportive relationships between leaders and followers 
improve followers' creativity (Shin \& Zhou, 2003). Leaders have thus traditionally been considered a crucial factor in the cultivation or suffocation of employee creativity (George, 2007), with leaders' behavior playing a significant role in employees' creative thinking (Zhang, Tsui, \& Wang, 2011). A variety of studies have sought to understand the role of positive leadership —including transformational leadership (Gong, Huang, \& Farh, 2009; Shin \& Zhou, 2003) and ethical leadership (Ma \& Cheng, 2013) —in employee creativity.

Ilies et al. (2005) have suggested that followers of authentic leaders get more intrinsically motivated due to support provided by leaders to enhance their self-determination, while the motivation promotes creativity (Zhou \& Ren, 2012). Authentic leaders understand their strengths, weaknesses, values, beliefs, and emotions (i.e., self-awareness) and present their authentic selves to followers (i.e., relational transparency). In addition, these leaders analyze all relevant information before making decisions (i.e., balanced processing of information), and they are guided by moral values and standards (i.e., internalized moral perspective). Therefore, these leaders inspire trust and positive achievement, which stimulate "thinking outside the box" and enhance the emotional safety needed to be creative (Avolio et al., 2004). Authentic leaders allow followers to trust their supervisors enough to take risks and be creative.

Authentic leaders also promote positive interactions (George, 2003) and increase employees' positive emotions. These emotions create the urge to play, adopt unconventional thinking, and be creative (Wright \& Cropanzano, 2004). As the latter cited authors explain, these emotions promote wellbeing at work, increasing employees' desire to explore and assimilate innovative ideas, discover fresh information, and develop their individual potentialthereby inducing workers to be more creative.

In summary, employees' perceptions of AL promote positive emotions, which, in turn, stimulate their creativity (e.g., Fredrickson, 2003; Gavin \& Mason, 2004). AL has also been more specifically linked with followers' creativity (e.g., Ilies et al., 2005; Li, Yu, Yang, Qi, \& 
Fu, 2014; Rego et al., 2014; Walumbwa et al., 2008; Zhou, Ma, Cheng, \& Xia, 2014), including more recent research showing that AL has a positive relationship with individual creativity (Banks et al., 2016; Černe et al., 2013; Semedo et al., 2016, 2017). In view of these findings, the following hypothesis was proposed for the present study:

H2: Employees' perceptions of AL are positively related with their creativity.

\section{Affective commitment and creativity}

Given that creativity can be understood as the production of new ideas and solutions (Amabile, 1988), it may be related to the bond that employees believe they have with their organization (Semedo et al., 2016). Consequently, affective commitment can play an important role in creative behavior. That is, employees who demonstrate greater affective commitment tend to exhibit more creative behaviors (Binnewies, Ohly, \& Niessen, 2008; Organ \& Ryan, 1995).

According to Isen, Daubman, and Nowicki (1987), happier people tend to be more creative, and, if individuals experience happiness at work, they develop an affective attachment to their workplace (Rego, Ribeiro, Cunha, \& Jesuino, 2011). Fredrickson (2001) suggests that positive emotions actively broaden the scope of individuals' attention and cognition, enabling flexible and creative thinking to guide their behavior. Lyubomirsky, King, and Diener (2005) mention various studies that indicate happiness and positive affect positively influence creativity, flexible thinking, and originality. Positive affect thus correlates positively with creativity in organizations because this affect makes additional cognitive material available for processing and leads to defocused attention that increases cognitive flexibility. Positive affect increases the probability that individuals will associate diverse cognitive elements (Amabile, Barsade, Mueller, \& Staw, 2005). 
Semedo et al. (2016) recently confirmed that employees' affective commitment predicts their creativity. Creative behavior is related to workers' autonomy, persistence, professional achievement, and dedication to work (Rice, 2006). These features stimulate the establishment of affectionate bonds between employees and organizations and define the ways that employees' creativity is influenced by their workplace (Semedo et al., 2016). From a social exchange perspective, employees with strong affective commitment can be expected to invest in creating and applying novel solutions that help improve organizational effectiveness (Montani, Courcy, \& Vandenberghe, 2017).

To summarize, when employees are affectively committed to their organization, they tend to develop more creative behavior. Given these previous results, the following hypothesis was proposed for the present study:

H3: Employees' affective commitment is positively related with their creativity.

\section{Affective commitment as a mediator of the relationship between $A L$ and creativity}

Followers of authentic leaders get more intrinsically motivated (Ilies et al., 2005), and through the intrinsic motivation caused by feeling meaningful and valuable, employees feel at liberty to engage in voice behaviors (Chen, Wang, \& Lee, 2018) and speak out with new ideas. Dedahanov, Lee, Rhee and Yoon (2918) suggested that moral leadership style facilitates employee voice which in turn impacts on creativity. Authentic leaders' transparency and trust allows employees the freedom to innovate without fear of reprisal.

Authenticity can enhance leaders' ability to improve the quality of workplace conditions and social climate, so leaders may play an important role in how much employees develop more positive attitudes and creativity.

According to George (2003), leaders who act with their "heart", they are more likely to create closer relationships with their followers. Prior research has suggested that the quality of 
exchanges between employees and leaders could explain attitudinal responses such as affective commitment (e.g., Gertsner \& Day, 1997). Because authentic leaders value self-awareness, encourage transparency in their relationships with others, display an internal moral perspective, and demonstrate balanced processing, they influence employees' emotional attachment to their organization (Avolio et al., 2004). In turn, when employees are affectively committed to their workplace, they develop more creative ideas (Organ \& Ryan, 1995; Semedo et al., 2016).

Employees are predisposed to finding solutions for work problems each day, overcoming any obstacles encountered, and seeking ways to effectively address challenges at work (Licata, Mowen, Harris, \& Brown, 2003) in creative ways — but workers do so particularly when they feel affectively committed. Moreover, employees are more affectively committed when they perceive their leaders' authenticity as deep-seated (Darvish \& Rezaei, 2011; Leroy et al., 2012). Thus, the following hypothesis was proposed for the current research:

H4: Employees' affective commitment mediates the relationship between AL and their creativity.

\section{Method}

\section{Sample}

This study focused on 26 private, small and medium-sized enterprises (SMEs) operating in Portugal. Data were collected from a convenience sample of 177 leader-follower dyads. The respondents had a mean age of 31.44 years (standard deviation $[\mathrm{SD}]=7.30$, minimum $=20$ years; maximum $=57$ years), and 55.0\% were females. Most respondents $(63.6 \%)$ had between 7 and 12 years of schooling, but $29.9 \%$ had a higher education degree and $6.8 \%$ had completed 6 years of schooling or less. Concerning job tenure, the followers had been employed in their organizations for at least 1 year, with a mean tenure of 6.12 years $(\mathrm{SD}=4.36$ years; maximum $=25$ years). The average contact time of each follower with his or her leader was 5.56 years 
$(\mathrm{SD}=3.96$ years; minimum $=1$ year; maximum $=23$ years $)$. The organizations were from different sectors, including office supplies, food, construction, and automobiles.

\section{Procedure}

Several organizations were invited to take part in the study. After they agreed, the individuals in charge of each organization's work teams and/or departments were identified and asked to participate in the study. Each supervisor was explicitly informed that the study involved collecting data from leader-follower dyads. If the leaders granted their consent, paperand-pencil questionnaires were delivered to them and their followers.

The research goals were explained to the respondents, and their anonymity and the confidentiality of their data were guaranteed. To avoid the risk of demand characteristics affecting the study's outcomes, the research goals were presented in quite vague terms. The participants were told that the study was about "employees' behaviors and opinions regarding various aspects of their work situation." The topics of AL, affective commitment, and creativity were purposely not mentioned to participants.

The respondents were asked to answer questions as honestly as possible, and the instructions explicitly stated that there were no right or wrong answers. Instructions were also provided regarding how to complete the questionnaire, in order to reduce the possibility of errors. To avoid any embarrassment, leaders and followers were asked to complete the survey in separate locations and, upon completion, to place the questionnaires in the envelopes provided and seal them. According to Podsakoff, Mackenzie, Lee and Podsakoff (2003), protecting participant anonymity and diminishing evaluation apprehension contribute to reducing lenient, acquiescent, and socially desirable answers.

Followers were asked to report their affective commitment and perceptions of AL, and leaders were asked to assess their followers' individual level of creativity, for a maximum of 
six employees per supervisor. Collecting data about dependent and independent and/or mediating variables from different sources is important to reduce common-method variance (CMV) (Podsakoff et al., 2003). To reduce CMV further, different formats and/or ranges were used for the relevant measures (Podsakoff et al., 2003). Both leader and follower questionnaires had items regarding the respondents' age, gender, education, tenure in their organization, and tenure in their dyads (i.e., length of time in leader-follower dyads).

\section{Measures}

\section{Predictive variable}

AL was measured using the 16-item scale developed by Walumbwa et al. (2008) and previously translated into Portuguese by Rego et al. (2012). The 16 items assessed four dimensions: self-awareness, relational transparency, internalized moral perspective, and balanced processing. Followers reported how often their leaders adopted each behavior on a 5point Likert scale ( $1=$ "Never" to $5=$ "Often, if not always").

As has been done in relevant studies in the literature on AL (e.g., Rego et al., 2012; Rego et al., 2013; Semedo et al., 2016; Walumbwa et al., 2008), confirmatory factor analysis (CFA) was carried out to test the second-order factor model, using SPSS Amos 22.0 software. Bootstrapping (Efron, 1992) was used to ensure a robust sampling distribution, as this technique

calculates "the statistic of interest in multiple re-samples of the dataset and by sampling $n$ units with replacement from the original sample of $n$ units" (Preacher, Rucker, \& Hayes, 2007, p. 190).

The following criteria were considered to estimate the models' fit (Hu \& Bentler, 1999; Kline, 2005; Marsh, Hau, \& Wen, 2004). The root mean square error of approximation (RMSEA) requires values equal or below 0.08 to be acceptable. The goodness of fit index (GFI) needs to have values equal to or higher than 0.90 to be satisfactory. The comparative fit index 
(CFI) requires values equal to or higher than 0.90 to be acceptable. The Tucker-Lewis index (TLI) should have values equal to or higher than 0.90 to be satisfactory. Finally, the chi-square to degrees of freedom ratio $\left(\chi^{2} / \mathrm{df}\right)$ must have values below $2-3$ to be acceptable.

Since the RMSEA was higher than the 0.08 cutoff value, standardized residuals and modification indices were analyzed to locate sources of misspecification. After considering the results obtained with both techniques, four items were removed: one for balanced processing and three for relational transparency. A well-fitted, 12-item second-order factor model emerged (see Table 1). A first-order factor model, in which AL's four dimensions were intercorrelated, also fit the data adequately. Nevertheless, the second-factor model was selected for testing the hypotheses because of its parsimony compared with the four-factor model and because the four dimensions of AL were highly correlated, which, in turn, shows the existence of a latent variable or factor (Marôco, 2014).

\section{Please insert Table 1}

To obtain a composite AL score, the procedure suggested by Luthans, Norman, Avolio and Avey (2008) was followed. Thus, the values of the items assessing each of the four dimensions were first calculated to obtain a composite average for each dimension. Then, the averages for each of the four dimensions were calculated to arrive at a composite AL score for each follower (alpha $[\alpha]=0.94)$. Higher scores represent perceptions of stronger AL. To test the impact of removing the four items, the correlation between the scores computed with the final set versus the initial set of items was calculated. The resulting value was 0.99 .

\section{Mediator variable}

Followers' affective commitment levels were measured using four items adapted from Meyer, Allen and Smith's (1993) scale (e.g., "This organization has great personal meaning to me"). The Portuguese version used had previously been translated and back-translated by Rego 
and Cunha (2008) and Rego, Cunha and Souto (2007). Followers indicated how much each item applied to them on a 7-point Likert scale $(1=$ "This statement does not apply to me at all" to $7=$ "This statement applies to me completely"). The CFA's results show that the measure presents factor loadings ranging from 0.76 to 0.95 and fits the data well $\left(\chi^{2}=3.148\right.$ [2]; $p>$ $0.05 ; \chi 2 / \mathrm{df}=1.574 ; \mathrm{GFI}=0.991 ; \mathrm{CFI}=0.998 ; \mathrm{TLI}=0.994 ; \mathrm{RMSEA}=0.057)$. To obtain a composite affective commitment score, the items were averaged $(\alpha=0.92)$. Higher scores represent stronger affective commitment.

\section{Criterion variable}

Individual creativity was measured using an adapted version of the 13-item scale developed and validated by Zhou and George (2001) (e.g., "This employee . . . is not afraid to take risks"). The translation of these items into Portuguese followed Brislin and Berry's (1986) recommendations. Leaders indicated how characteristic the 13 behaviors were of each follower on a 5-point Likert scale ( $1=$ "Not at all characteristic" to $5=$ "Very characteristic"). The CFA's results show that the measure presents factor loadings ranging from 0.66 to 0.94 and fits the data well $(\chi 2=129.060$ [65]; $\mathrm{p}<0.000 ; \mathrm{GFI}=0.897 ; \mathrm{CFI}=0.980 ;$ TLI $=0.976 ;$ RMSEA $=$ 0.075). To obtain a composite creativity score, the items were averaged ( $\alpha=0.98)$. Higher scores represent stronger perceptions of follower creativity.

\section{Confirmatory factor analyses for testing discriminant and convergent validity}

To examine whether the three variables of interest capture distinct constructs versus common-source effects, several CFAs were performed (see Table 2). The three-factor model fit the data well (e.g., RMSEA $=0.063 ; \mathrm{GFI}=0.803 ; \mathrm{TLI}=0.948 ; \mathrm{CFI}=0.952$ ), while the singlefactor model and three other alternative models presented unacceptable fit statistics. These results indicate the discriminant validity of AL, affective commitment, and individual creativity. 


\section{Please insert Table 2}

The composite reliability (CR) and average variance extracted (AVE) of all variables were also obtained (see Table 3). Based on Hair, Black, Babin and Anderson's (2010) recommendations, the variables were judged to have appropriate CR (i.e., ranging from 0.93 to 0.98 ) and AVE scores (i.e., ranging 0.76 to 0.86 ), thereby supporting convergent validity.

\section{Please insert Table 3}

\section{Results}

Table 3 above presents the means, SDs, CRs, AVEs, and correlations between the variables, showing that all the variables are positively and significantly correlated with each other. Employees' perceptions of AL are strongly correlated with their affective commitment and moderately correlated with their creative behavior. The latter behavior is also moderately correlated with employees' emotional attachment to their organizations.

Regarding the socio-professional variables, education correlates positively with creativity and overall AL. Tenure in dyad correlates positively with overall AL, affective commitment, and creativity. Tenure in organization also correlates positively with all the variables. Tenure in dyad and tenure in organizations are strongly correlated with each other. Therefore, only one of these variables was included in subsequent analyses, namely, tenure in dyad. Gender and age are not significantly correlated with the mediator and criterion variables, so gender and age were excluded from the analyses.

Hypotheses were tested using Structural Equation Modeling (SEM). The respondents' education and tenure in dyad were set as control variables. The analysis of the goodness of fit of the proposed theoretical model confirmed a good fit to the data $\left(\chi^{2}[427]=719.666 ; p<\right.$ $\left.0.000 ; \chi^{2} / \mathrm{df}=1.685 ; \mathrm{RMSEA}=0.062 ; \mathrm{GFI}=0.795 ; \mathrm{CFI}=0.947 ; \mathrm{TLI}=0.947\right)($ see Table 2 , Model 6 above). The analysis of the estimates (see Table 4) showed that AL exerts a positive 
and statistically significant effect on affective commitment (beta $[\beta]=0.812 ; p<0.001$ ). The stronger the perceptions of AL are, the stronger the employees' affective bond to their organizations is. H1 was thus supported.

\section{Please insert Table 4}

The AL variable also positively and significantly influences individual creativity $(\beta=$ $0.480 ; p<0.001)$. This result suggests that the more authentic leader are, the more creative their followers' behaviors are at work, thus confirming $\mathrm{H} 2$.

In addition, affective commitment has a positive, statistically significant influence on individual creativity $(\beta=0.500 ; p<0.001)$, indicating that creative behaviors become more frequent as employees' affective relationship with their organizations becomes stronger. $\mathrm{H} 3 \mathrm{was}$, therefore, supported.

Regarding $\mathrm{H} 4$, the results reveal that the total effect of AL on creativity is significant $(\beta$ $=0.480 ; p<0.001)$ and so is AL's indirect effect through affective commitment $(\beta=0.406 ; p$ $<0.001)$. However, the effect of AL on creativity is no longer statistically significant when affective commitment is included in the model (i.e., direct effect) $(\beta=0.073$; n.s.). This evidence confirms the complete mediation of affective commitment in the relationship between perceived AL and individual creativity, thus supporting H4. In addition, the fit indices of a full mediated model, that is, a model without the path between AL and creativity, are similar to the theoretical model (see Table 2 above). Accordingly, perceptions of AL appear to increase followers' affective commitment to their organizations, and this subsequently enhances their creative behavior at work (see Figure 1).

\section{Please insert Figure 1}

\section{Discussion and Conclusions}

\section{Main findings}


This study provides empirical evidence that AL promotes employees' affective commitment to and creativity in their workplace. These findings are consistent with other studies reporting that employees' perceptions of their leaders' authenticity promote these workers' affective bond to their organization (e.g., Avolio et al., 2004; Darvish \& Rezaei, 2011; Gardner et al., 2005; Leroy et al., 2012; Rego et al., 2013), as well as their individual creativity (e.g., Banks et al., 2016; Černe et al., 2013; Semedo et al., 2016, 2017). More specifically, by being relationally transparent, behaving honestly, and processing information in balanced ways, authentic leaders contribute to developing open, truthful relationships with their followers. AL thus creates a positive work environment in which affective commitment and creativity are promoted and encouraged.

The present results further reveal that employees' affective commitment explains their creativity. This finding coincides with prior literature, which reports that affectively committed employees tend to exhibit more creative behavior (Organ \& Ryan, 1995; Semedo et al., 2016, 2017). The production of innovative ideas and solutions can be related to the bond that employees believe they have with their organization (Binnewies et al., 2008). Workers who feel an affective attachment to their workplace are more committed to investing in that organization's success by making more suggestions, participating more in innovative activities, and using their intellect in creative behaviors at work. Therefore, employees' affective commitment is crucial to their creative behavior.

The current study's results reveal a full mediation of affective commitment in the relationship between workers' perceptions of AL and their creativity. This finding suggests that perceived AL can stimulate employees' affective attachment to the organization, which, in turn, promotes their creativity. Certain characteristics of authentic leaders contribute to establishing higher quality exchanges with their followers because these managers inspire hope, confidence, optimism, and positive emotions in employees, who reciprocate with higher affective 
commitment (Paillé, 2009; Rego et al., 2014). Employees must also be psychologically comfortable in order to be creative (West \& Altink, 1996). That is, when employees perceive their leaders' authenticity, they are much more emotionally committed (Darvish \& Rezaei, 2011; Leroy et al., 2012; Rego et al., 2013; Semedo et al., 2016), and employees' emotional bonds to the organization influence their creativity, as other studies have shown (e.g., Organ \& Ryan, 1995; Semedo et al., 2016).

\section{Limitations and future research}

The present study has some limitations that indicate further research is needed to understand better how AL impacts employee creativity. One limitation is convenience sampling, which restricts the results' generalizability. In addition, the correlational and cross-sectional research design does not allow firm conclusions to be drawn about the causal nexus between the study's variables. Future research needs to examine possible causal relationships using longitudinal studies.

The respondents in this research came from a single country and worked in private SMEs. Further studies could test if the present empirical findings can be replicated in different countries with different cultures. The study further included only one mediating variable, but others are also plausible (e.g., organizational identification, meaningfulness at work, and perceived organizational support). Future research might include these variables as mediators, investigating more fully the psychosocial mechanisms through which perceptions of $\mathrm{AL}$ promote employees' affective commitment and creativity. For example, authentic leaders could increase perceived organizational support, which, in turn, increases employees' creativity.

Further studies may also want to analyze how personal characteristics intervene in the relationship between AL and individual creativity (e.g., employees' creativity, self-efficacy, and risk-taking). All things considered, this study's findings open up new avenues of research in the 
field of positive organizational scholarship that could lead to a fuller understanding of the influence of AL on employees' attitudes and behaviors.

\section{Theoretical contributions}

This study answers the call for additional empirical research to examine more closely how AL influences employees' responses, as well as to expand AL theory's nomological network and assess this theory's validity and stability across culturally diverse samples (Avolio \& Mhatre, 2012; Gardner et al., 2011; Hsieh \& Wang, 2015; Leroy et al., 2012; Walumbwa et al., 2008). The results of the present investigation contribute to explaining this relationship because they support the theoretical development of and new empirical research in this field. Therefore, the quality of relationships between authentic leaders and their followers and the positive work environment created by these leaders may play an important role in the extent to which employees develop more positive attitudes and creativity, which benefit their organization.

To date, few studies have examined AL's relationships with creativity (e.g., Banks et al., 2016; Černe et al., 2013; Semedo et al., 2017) and affective commitment (e.g., Leroy et al., 2012; Rego et al., 2013; Semedo et al., 2016), so the current research sought to incorporate these constructs into a single research model. In particular, the mediating role of affective commitment in the relationship between AL and employees' creativity has been underexplored in the literature. Thus, this study filled a research gap by analyzing this mediation, that is, by examining affective commitment as a mediating mechanism of the relationship between AL and creativity. The present findings add further relevant insights to AL theory. In addition, this research's results were produced using a rigorous empirical methodology that included collecting data via a double-source method and thereby reduced the risk of common-method bias. 


\section{Managerial implications}

This study makes significant practical contributions by showing that organizations need to not only identify and select employees with personal attributes that make them more creative but also create work conditions that support creativity, including AL. The present findings indicate that managers and organizations can create an atmosphere of admiration, respect, participation, and involvement for their employees, which will in turn help to enhance their commitment and creativity. Therefore, organizations need to select, develop, and invest in managers who adopt a more AL style. Some suggestions to help leaders achieve this are as follows:

(1) Engage in behaviors that are consistent with their words and values

(2) Admit mistakes that they have made and encourage followers to do the same

(3) Seek to become more aware of their own moral weaknesses when pressured by external influences

(4) Develop a 360-degree feedback process that provides them with anonymous feedback from their superior, peers, and followers, thus facilitating better decisions

(5) Share information openly and impart sincere feelings, emotions, and thoughts to followers

(6) Give their followers the freedom to choose which initiatives they take because this is vital to developing their creativity

(7) Act in respectful, honest, optimistic, courteous, and supportive ways, nurturing their credibility and followers' commitment and creativity

Indirectly, this study's findings also suggest that organizations need to focus on selecting managers with authentic traits and implementing appropriate training, coaching, and development activities that generate more AL. These initiatives can have a positive effect on their employees' attitudes and creative behaviors. 


\section{Compliance with Ethical Standards}

\section{Ethical Approval}

All procedures performed in studies involving human participants were in accordance with the ethical standards of the institutional and/or national research committee and with the 1964 Declaration of Helsinki and its later amendments or comparable ethical standards.

\section{Informed Consent}

Informed consent was obtained from all individual participants included in the study.

\section{References}

Allen, N. J., \& Meyer, J. P. (1990). The measurement and antecedents of affective, continuance and normative commitment to the organization. Journal of Occupational Psychology, 63, 1-18.

Allen, N. J., \& Meyer, J. P. (1996). Affective, continuance, and normative commitment to the organization: An examination of construct validity. Journal of Vocational Behavior, 49, $252-$ 276.

Alshammari, A., Almutairi, N., \& Thuwaini, F. (2015). Ethical leadership: The effect on employees. International Journal of Business and Management, 10 (3), 108-116.

Alzghoul, A., Elrehail, H., Emeagwali, O. L., \& AlShboul, M. K. (2018). Knowledge management, workplace climate, creativity and performance: The role of authentic Leadership. Journal of Workplace Learning, 30(8), 592-612.

Amabile, T., Barsade, S., Mueller, J., \& Staw, B. (2005). Affect and creativity at work. Administrative Science Quarterly, 50(3), 367-403.

Amabile, T. M. (1988). A model of creativity and innovation in organizations. In B. M. Staw, \& L. L. Cummings (eds.), Research in organization behavior (pp. 10). Greenwich, CT: JAI 
Press.

Arda, Ö. A., Aslan, T., \& Alpkan, L. (2016). Review of practical implications in authentic leadership studies. Procedia-Social and Behavioral Sciences, 229, 246-252.

Avolio, B. (2005). Leadership development in balance: Made/born. Mahwah, NJ: Lawrence Erlbaum.

Avolio, B. J., \& Gardner, W. L. (2005). Authentic leadership development: Getting the root of positive forms of leadership. The Leadership Quarterly, 16(3), 315-338.

Avolio, B. J., Gardner, W. L., Walumbwa, F. O., Luthans, F., \& May, D. R. (2004). Unlocking the mask: A look at the process by which authentic leaders impact follower attitudes and behaviors. The Leadership Quarterly, 15(6), 801-823.

Avolio, B. J., \& Luthans, F. (2006). The high impact leader: Moments matter in accelerating authentic leadership development. New York: McGraw-Hill.

Avolio, B. J., \& Mhatre, K. H. (2012). Advances in theory and research on authentic leadership. In K. S. Cameron, \& G. Spreitzer (eds.), The Oxford handbook of positive organizational scholarship (pp. 773-783). Oxford: Oxford University Press.

Avolio, B. J., Walumbwa, F. O., \& Weber, T. J. (2009). Leadership: Current theories, research, and future directions. Annual Review of Psychology, 60(1), 421-449.

Avolio, B. J., Wernsing, T., \& Gardner, W. L. (2018). Revisiting the development and validation of the Authentic Leadership Questionnaire: Analytical clarifications. Journal of Management, 44(2), 399-411.

Banks, G. C., McCauley, K. D., Gardner, W. L., \& Guler, C. E. (2016). A meta-analytic review of authentic and transformational leadership: A test for redundancy. The Leadership Quarterly, 27(4), 634-652. 
Baron, L. (2016). Authentic leadership and mindfulness development through action learning. Journal of Managerial Psychology, 31(1), 296-311.

Barron, F. B., \& Harrington, D. M. (1981). Creativity, intelligence, and personality. Annual Review of Psychology, 32(1), 439-476.

Bass, B. M., \& Riggio, R. E. (2006). Transformational leadership. London: Psychology Press. Binnewies, C., Ohly, S., \& Niessen, C. (2008). Age and creativity at work: The interplay between job resources, age and idea creativity. Journal of Managerial Psychology, 23(4), $438-457$.

Brislin, R. W. and Berry, J. W. (1986). The wording and translation of research instrument. In W. J. Lonner (ed.), Field methods in cross-cultural research (pp. 137-164). Sage Publications, Beverly Hills, CA.

Brown, M. E., Treviño, L. K., \& Harrison, D. A. (2005). Ethical leadership: A social learning perspective for construct development and testing. Organizational Behavior and Human Decision Processes, 97(2), 117-134.

Černe, M., Jaklič, M., \& Škerlavaj, M. (2013). Authentic leadership, creativity, and innovation: A multilevel perspective. Leadership, 9(1), 63-85.

Chen, S., Wang, M., \& Lee, S. H. (2018). Transformational leadership and voice behaviors: The mediating effect of employee perceived meaningful work. Personnel Review, 47(3), 694708.

Crossan, M., \& Apaydin, M. (2010). A multi-dimensional framework of organizational innovation: a systematic review of the literature. Journal of Management Studies, 47(6), 1154-1191.

Darvish, H., \& Rezaei, F. (2011). The impact of authentic leadership on job satisfaction and 
team commitment. Management \& Marketing Challenges for the Knowledge Society, 6(3), $421-436$.

Dedahanov, A. T., Lee H., Rhee, J., \& Yoon, J. (2016). Entrepreneur's paternalistic leadership style and creativity: The mediating role of employee voice. Management Decision, 54(9), 2310-2324.

Delić, M., Delić, M., Slåtten, T., Slåtten, T., Milić, B., Milić, B., . . \& \& Vulanović, S. (2017). Fostering learning organisation in transitional economy - the role of authentic leadership and employee affective commitment. International Journal of Quality and Service Sciences, 9(34), 441-455.

Efron, B. (1992). Bootstrap methods: Another look at the jackknife. In S. Kotz \& N.L. Johnson (eds.), Breakthroughs in statistics (pp. 569-593). New York, NY: Springer.

Fredrickson, B. (2001). The role of positive emotions in positive psychology: The broadenand-build theory of positive emotions. The American Psychologist, 56(3), 218-226.

Fredrickson, B. (2003). The value of positive emotions. American Scientist, 91(4), 330-335. Gardner, W., Avolio, B., Luthans, F., May, D., \& Walumbwa, F. (2005). Can you see the real me? A self-based model of authentic leader and follower development. The Leadership Quarterly, 16(3), 343-372.

Gardner, W. L., Cogliser, C. C., Davis, K. M., \& Dickens, M. P. (2011). Authentic leadership: A review of the literature and research agenda. The Leadership Quarterly, 22(6), 1120-1145.

Gavin, J. H., \& Mason, R. O. (2004). The virtuous organization: The value of happiness in the workplace. Organizational Dynamics, 33(4), 379-392.

George, B., Sims, P., McLean, A. N., \& Mayer, D. (2007). Discovering your authentic leadership. Harvard Business Review, February, 1-10. 
George, J., \& Zhou, J. (2007). Dual tuning in a supportive context: Joint contributions of positive mood, negative mood, and supervisory behaviors to employee creativity. Academy of Management Journal, 50(3), 605-622.

George, M. J. (2007). Creativity in organizations. Academy of Management Annals, 1(1), 439-477.

George, W. (2003). Authentic leadership: Rediscovering the secrets to creating lasting value. San Francisco: Jossey-Bass.

Gertsner, C. R., \& Day, D. V. (1997). Meta-analytic review of leader-member exchange theory: Correlates and construct issues. Journal of Applied Psychology, 82(6), 827-844. Gong, Y., Huang, J., \& Farh, J. (2009). Employee learning orientation, transformational leadership, and employee creativity: The mediating role of employee creative self-efficacy. Academy of Management Journal, 52(4), 765-778.

Hair Jr., J. F., Black, W. C., Babin, B. J., \& Anderson, R. E. (2010). Multivariate data analysis: A global perspective (7th ed.). Upper Saddle River, NJ: Pearson.

Hsieh, C.-C., \& Wang, D.-S. (2015). Does supervisor-perceived authentic leadership influence employee work engagement through employee-perceived authentic leadership and employee trust? The International Journal of Human Resource Management, 26 (18), 2329-2348, Hu, L., \& Bentler, P. (1999). Cutoff criteria for fit indexes in covariance structure analysis: Conventional criteria versus new alternatives. Structural Equation Modeling, 6, 1-55.

Ilies, R., Morgeson, F. P., \& Nahrgang, J. D. (2005). Authentic leadership and eudaemonic well-being: Understanding leader-follower outcomes. The Leadership Quarterly, 16(3), 373394.

Isen, M., Daubman, A., \& Nowicki, P. (1987). Positive affect facilitates creative problem 
solving. Journal of Personality and Social Psychology, 52, 1122-1131.

Javaid, M. F., Luqman, K., Amir, H., \& Umair, T. (2015). Authentic leadership affects employee's attitudes (affective commitment) through the mediation role of personal identification and organizational identification. International Journal of Academic Research in Business and Social Sciences, 5(12), 215-231.

Joo, B-K., \& Jo, S. J. (2017). The effects of perceived authentic leadership and core selfevaluations on organizational citizenship behavior: The role of psychological empowerment as a partial mediator. Leadership \& Organization Development Journal, 38(3), 463-481.

Kernis, M. H. (2003). Towards a conceptualization of optimal self-esteem. Psychological Inquiry, 14(1), 1-26.

Kernis, M. H., \& Goldman, B. M. (2005). From thought and experience to behavior and interpersonal relationships: A multicomponent conceptualization of authenticity. In A. Tesser, J. V. Wood, \& D. Stapel (eds.), On building, defending and regulating the self: A psychological perspective (pp. 31-52). New York: Psychology Press.

Kline, R. (2005). Principles and practice of structural equation modelling. New York: Guilford Press.

Leroy, H., Palanski, M., \& Simons, T. (2012). Authentic leadership and behavioral integrity as drivers of follower commitment and performance. Journal of Business Ethics, 107(3), 255264.

Li, F., Yu, K. F., Yang, J., Qi, Z., \& Fu, J. H. (2014). Authentic leadership, traditionality, and interactional justice in the Chinese context. Management and Organization Review, 10(2), 249-273.

Licata, J. W., Mowen, J. C., Harris, E. G., \& Brown, T. J. (2003). On the trait antecedents and outcomes of service worker job resourcefulness: A hierarchical model approach. Journal of 
the Academy of Marketing Science, 31(3), 256-271.

Luthans, F., Norman, S. M., Avolio, B., \& Avey, J. B. (2008). The mediating role of psychological capital in the supportive organizational climate-employee performance relationship. Journal of Organizational Behaviour, 29(2), 219-239.

Lyubomirsky, S., King, L., \& Diener, E. (2005). The benefits of frequent positive affect: Does happiness lead to success? Psychological Bulletin, 131(6), 803-855.

Ma, Y., \& Cheng, W. (2013). Linking ethical leadership to employee creativity: Knowledge sharing and self-efficacy as mediators, social behavior and personality. Social Behavior and Personality, 41, 1409-1419.

Madjar, N., Oldham, G. R., \& Pratt, M. G. (2002). There's no place like home: The contributions of work and nonwork creativity support to employees' creative performance. Academy of Management Journal, 45(4), 757-767.

Marôco, J. (2014). Análise de equações estruturais: Fundamentos teóricos, software e aplicações. Pêro Pinheiro: ReportNumber.

Marsh, H., Hau, K., \& Wen, Z. (2004). In search of golden rules: Comment on hypothesis testing approaches to setting cutoff values for fit indexes and dangers in overgeneralising $\mathrm{Hu}$ and Bentler's (1999) findings. Structural Equation Modelling, 11, 320-341.

Meyer, J. P., Allen, N. J. and Smith, C. A. (1993). Commitment to organizations and occupations: Extension and test of a three-component conceptualization. Journal of Applied Psychology, 78(4), 538-551.

Meyer, J.P. and Herscovitch, L. (2001). Commitment in the workplace: Toward a general model. Human Resources Management Review, 11, 299-326.

Meyer, J.P., Stanley, D., Herscovitch, L., \& Topolnytsky, L. (2002). Affective, continuance, 
and normative commitment to the organization: A meta-analysis of antecedents, correlates, and consequences. Journal of Vocational Behavior, 61, 20-52.

Montani, F., Courcy, F., \& Vandenberghe, C. (2017). Innovating under stress: The role of commitment and leader-member exchange. Journal of Business Research, 77, 1-13.

Muceldili, B., Turan, H., \& Erdil, O. (2013). The influence of authentic leadership on creativity and innovativeness. Procedia-Social and Behavioral Sciences, 99(6), 673-681.

Nazari, K., \& Emami, M. (2012). Leadership: A critical review of the concept. Interdisciplinary Journal of Contemporary Research in Business, 3(9), 545-553.

Organ, D. W., \& Ryan, K. (1995). A meta-analytic review of attitudinal and dispositional predictors of organizational citizenship behavior. Personnel Psychology, 48(4), 775-802. Paillé, P. (2009). The relationship between support, commitment and intent to leave team: A social exchange perspective. Team Performance Management, 15(1-2), 49-62.

Peus, C., Wesche, J. S., Streicher, B., Braun, S., \& Frey, D. (2012). Authentic leadership: An empirical test of its antecedents, consequences, and mediating mechanisms. Journal of Business Ethics, 107, 331-348.

Podsakoff, P., MacKenzie, S., Lee, J., \& Podsakoff, N. (2003). Common method biases in behavioral research: A critical review of the literature and recommended remedies. Journal of Applied Psychology, 88(5), 879-903.

Podsakoff, P. M., MacKenzie, S. B., \& Bommer, W. H. (1996). Transformational leader behaviors and substitutes for leadership as determinants of employee satisfaction, commitment, trust, and organizational citizenship. Journal of Management, 22(2), 259-298.

Preacher, K., Rucker, D., \& Hayes, A. (2007). Addressing moderated mediation hypotheses: Theory, methods and prescriptions. Multivariate Behavioral Research, 42, 185-227. 
Rafferty, A. E., \& Griffin, M. A. (2004). Dimensions of transformational leadership:

Conceptual and empirical extensions. The Leadership Quarterly, 15(3), 329-354.

Rego, A., \& Cunha, M. P. (2008). Workplace spirituality and organizational commitment: An empirical study. Journal of Organizational Change Management, 21(1), 53-75.

Rego, A., Cunha, M. P., \& Souto, S. (2007). Workplace spirituality, commitment and selfreported individual performance: An empirical study. Management Research, 5(3), 163-183.

Rego, A., Ribeiro, N., Cunha, M. P., \& Jesuino, J. C. (2011). How happiness mediates the organizational virtuousness and affective commitment relationship. Journal of Business Research, 64(5), 524-532.

Rego, A., Sousa, F., Marques, S., \& Cunha, M. P. (2012). Authentic leadership promoting employees' psychological capital and creativity. Journal of Business Research, 65(3), 429 437.

Rego, A., Sousa, F., Marques, S., \& Cunha, M. P. (2014). Hope and positive affect mediating the authentic leadership and creativity relationship. Journal of Business Research, 67(2), 200210.

Rego, A., Vitória, A., Magalhães, A., Ribeiro, N., \& Cunha, M. P. (2013). Are authentic leaders associated with more virtuous, committed and potent teams? The Leadership Quarterly, 24(1), 61-79.

Ribeiro, N. Gomes, D., \& Kurian, S. (2018). Authentic leadership and performance: the mediating role of employees' affective commitment. Social Responsibility Journal, 14(1), $213-225$.

Rice, G. (2006). Individual values, organizational context, and self-perceptions of employee creativity: Evidence from Egyptian organizations. Journal of Business Research, 59(2), 233 241. 
Semedo, A. S., Coelho, A., \& Ribeiro, N. (2016). Effects of authentic leadership, affective commitment and job resourcefulness on employees' creativity and individual performance. Leadership \& Organization Development Journal, 37(8), 1038-1055.

Semedo, A. S., Coelho, A., \& Ribeiro, N. (2017). Authentic leadership and creativity: The mediating role of happiness. International Journal of Organizational Analysis, 25(3), 395412.

Shalley, C. E., Zhou, J., \& Oldham, G. R. (2004). The effects of personal and contextual characteristics on creativity: Where should we go from here? Journal of Management, 30, 933-958.

Shamir, B., \& Eilam, G. (2005). What's your story?: A life-stories approach to authentic leadership development. The Leadership Quarterly, 16(3), 395-417.

Shin, S. J., \& Zhou, J. (2003). Transformational leadership, conservation, and creativity: Evidence from Korea. Academy of Management Journal, 46(6), 703-714.

Tu, Y. D., \& Lu, X. X. (2013). How ethical leadership influence employees' innovative work behavior: A perspective of intrinsic motivation. Journal of Business Ethics, 116(2), 441-455.

Walumbwa, F. O., Avolio, B. J., Gardner, W. L., Wernsing, T. S. and Peterson, S. J. (2008). Authentic leadership: Development and validation of a theory-based measure. Journal of Management, 34(1), 89-126.

West, A., \& Altink, M. (1996). Innovation at work: Individual, group, organizational, and sociohistorical perspectives. European Journal of Work and Organizational Psychology, 5(1), $3-11$.

Wright, T. A., \& Cropanzano, R. (2004). The role of psychological well-being in job performance: A fresh look at an age-old quest. Organizational Dynamics, 33(4), 338-351. 
Youssef, D. A. (2000). Organisational commitment: A mediator of the relationships of leadership behaviour with job satisfaction and performance in a non-western country. Journal of Managerial Psychology, 15(1), 6-28.

Yucel, I., McMillan, A. and Richard, O. C. (2014). Does CEO transformational leadership influence top executive normative commitment? Journal of Business Research 67(6), 1170 1177.

Zhang, A. Y., Tsui, A. S., \& Wang, D. X. (2011). Leadership behaviors and group creativity in Chinese organizations: The role of group processes. The Leadership Quarterly, 22, 851862.

Zhou, J. (2003). When the presence of creative coworkers is related to creativity: Role of supervisor close monitoring, developmental feedback, and creative personality. Journal of Applied Psychology, 88(3), 413-422.

Zhou, J., \& George, J. (2001). When job dissatisfaction leads to creativity: Encouraging the expression of voice. Academy of Management Journal, 44(4), 682-696.

Zhou, J., Ma, Y., Cheng, W., \& Xia, B. (2014). Mediating role of employee emotions in the relationship between authentic leadership and employee innovation. Social Behavior and Personality, 42(8), 1267-1278.

Zhou, J., \& Ren, R. (2011). Striving for creativity: building positive contexts in the workplace. In K.S. Cameron \& G.M Spreitzer (eds.), The Oxford Handbook of Positive Organizational Scholarship (pp. 97-109). New York: Oxford University Press.

Zhou, J., \& Shalley, C. E. (2003). Research on employee creativity: A critical review and directions for future research. In J. Martocchio (ed.), Research in personnel and human resource management (pp. 165-217). Oxford: Elsevier. 
Table 1: CFA of AL (completely standardized solution)

\begin{tabular}{|c|c|c|}
\hline & $\begin{array}{l}\text { First- } \\
\text { order } \\
\text { factor } \\
\text { model } \\
\end{array}$ & $\begin{array}{c}\text { Second- } \\
\text { order } \\
\text { factor } \\
\text { model }\end{array}$ \\
\hline Dimensions & $\begin{array}{l}\text { Factor } \\
\text { loading }\end{array}$ & $\begin{array}{c}\text { Factor } \\
\text { loading }\end{array}$ \\
\hline Relational transparency & $(0.55)^{1}$ & $(0.55)^{1}$ \\
\hline Item \#1 Encourages everyone to say what they think & 0.78 & 0.78 \\
\hline Item $\# 2$ & 0.71 & 0.71 \\
\hline Internalized moral perspective & $(0.86)^{2}$ & $(0.86)^{2}$ \\
\hline Item \#3 Keeps actions consistent with his/her beliefs and convictions & 0.75 & 0.75 \\
\hline Item \#4 & 0.75 & 0.75 \\
\hline Item \#5 & 0.84 & 0.84 \\
\hline Item \#6 & 0.78 & 0.78 \\
\hline Balanced processing & $(0.59)^{1}$ & $(0.59)^{1}$ \\
\hline Item \#7 Solicits views that challenge his/her deeply held positions & 0.74 & 0.74 \\
\hline Item $\# 8$ & 0.79 & 0.79 \\
\hline Self-awareness & $(0.86)^{2}$ & $(0.86)^{2}$ \\
\hline Item $\# 9$ & 0.83 & 0.83 \\
\hline Item \#10 Accurately describes how others view his/her capabilities & 0.73 & 0.73 \\
\hline Item \#11 & 0.79 & 0.79 \\
\hline Item \#12 & 0.78 & $\begin{array}{c}0.78 \\
(0.94)^{2}\end{array}$ \\
\hline \multicolumn{3}{|l|}{ Overall authentic leadership } \\
\hline Relational transparency & & 0.99 \\
\hline Internalized moral perspective & & 0.98 \\
\hline Balanced processing & & 0.96 \\
\hline Self-awareness & & 0.97 \\
\hline \multicolumn{3}{|l|}{ Fit indices } \\
\hline$\chi^{2}$ & 108.419 & 112.723 \\
\hline df & 50 & 52 \\
\hline$\chi^{2 / \mathrm{df}}$ & 2.168 & 2.168 \\
\hline RMSEA & 0.081 & 0.081 \\
\hline GFI & 0.905 & 0.900 \\
\hline CFI & 0.958 & 0.956 \\
\hline TLI & 0.944 & 0.944 \\
\hline
\end{tabular}

Notes: ${ }^{1}$ Pearson's correlation coefficients $;{ }^{2}$ Cronbach's alphas. 
Table 2: Fit indices

\begin{tabular}{lccccc}
\hline & $\chi 2(\mathrm{df})$ & RMSEA & GFI & TLI & CFI \\
\hline Model 1 Three-factor model & $631.310(310)$ & 0.063 & 0.803 & 0.948 & 0.952 \\
Model 2 Single-factor model & $2,066.521(377)$ & 0.160 & 0.319 & 0.669 & 0.693 \\
$\begin{array}{l}\text { Model 3 Two-factor model (AL } \\
\text { and affective commitment }\end{array}$ & $826.548(376)$ & 0.083 & 0.743 & 0.912 & .913 \\
$\quad$ merged + creativity) & & & & & \\
$\begin{array}{l}\text { Model 4 Two-factor model (AL } \\
\text { and creativity merged + }\end{array}$ & $1,683.882(376)$ & 0.141 & 0.395 & 0.743 & 0.762 \\
$\quad$ & & & & & \\
$\begin{array}{l}\text { Mffective commitment) } \\
\quad \text { (affective commitment and }\end{array}$ & $1,148.556(376)$ & 0.108 & 0.649 & 0.848 & 0.860 \\
$\quad$ creativity merged + AL) & & & & & \\
Model 6 Theoretical model $^{1}$ & $719.666(427)$ & 0.062 & 0.795 & 0.943 & 0.947 \\
Model 7 No direct path model $^{1}$ & $720.022(428)$ & 0.062 & 0.795 & 0.943 & 0.947 \\
\hline
\end{tabular}

Note: ${ }^{1}$ Respondents' education and tenure in dyad entered as control variables. 
Table 3: Means, SDs, correlations, Cronbach's alphas, CRs, and AVEs

\begin{tabular}{|c|c|c|c|c|c|c|c|c|c|c|}
\hline & $\mathrm{M}$ & $\mathrm{SD}$ & 1 & 2 & 3 & 4 & 5 & 6 & $\mathrm{CR}$ & AVE \\
\hline 1. Education ${ }^{1}$ & - & - & & & & & & & - & - \\
\hline $\begin{array}{l}\text { 2. Tenure in } \\
\text { dyad }\end{array}$ & 5.56 & 3.96 & $0.17^{*}$ & & & & & & - & - \\
\hline $\begin{array}{l}\text { 3. Tenure in } \\
\text { organization }\end{array}$ & 6.12 & 4.36 & 0.07 & $0.88^{* *}$ & & & & & - & - \\
\hline 4. Overall AL & 4.00 & 0.71 & $0.17^{*}$ & $0.31^{* *}$ & $0.26^{* *}$ & $(0.94)$ & & & 0.96 & 0.86 \\
\hline $\begin{array}{l}\text { 5. Affective } \\
\text { commitment }\end{array}$ & 5.38 & 1.31 & 0.01 & $0.29^{* *}$ & $0.29^{* *}$ & $0.79^{* *}$ & $(0.92)$ & & 0.93 & 0.76 \\
\hline $\begin{array}{l}\text { 6. Individual } \\
\text { creativity }\end{array}$ & 3.87 & 0.94 & $0.19^{*}$ & $0.41^{* *}$ & $0.37^{* *}$ & $0.64^{* *}$ & $0.66^{* *}$ & $(0.98)$ & 0.98 & 0.80 \\
\hline
\end{tabular}


Table 4: SEM—hypotheses testing

\begin{tabular}{llccc}
\hline Hypotheses & Relationships & Estimate & P-value & Conclusion \\
\hline H1 & AL $\rightarrow$ affective commitment & 0.812 & 0.001 & Supported \\
H2 & AL $\rightarrow$ creativity (total effect) & 0.480 & 0.001 & Supported \\
H3 & $\begin{array}{l}\text { Affective commitment } \rightarrow \\
\text { creativity }\end{array}$ & 0.500 & 0.001 & Supported \\
H4 & $\begin{array}{l}\text { AL } \rightarrow \text { affective commitment } \rightarrow \\
\text { creativity (direct effect) }\end{array}$ & 0.073 & n.s. & Supported \\
& & & & \\
\hline
\end{tabular}


Figure 1: Structural equation modeling for predicting individual creativity (standardized path coefficients)

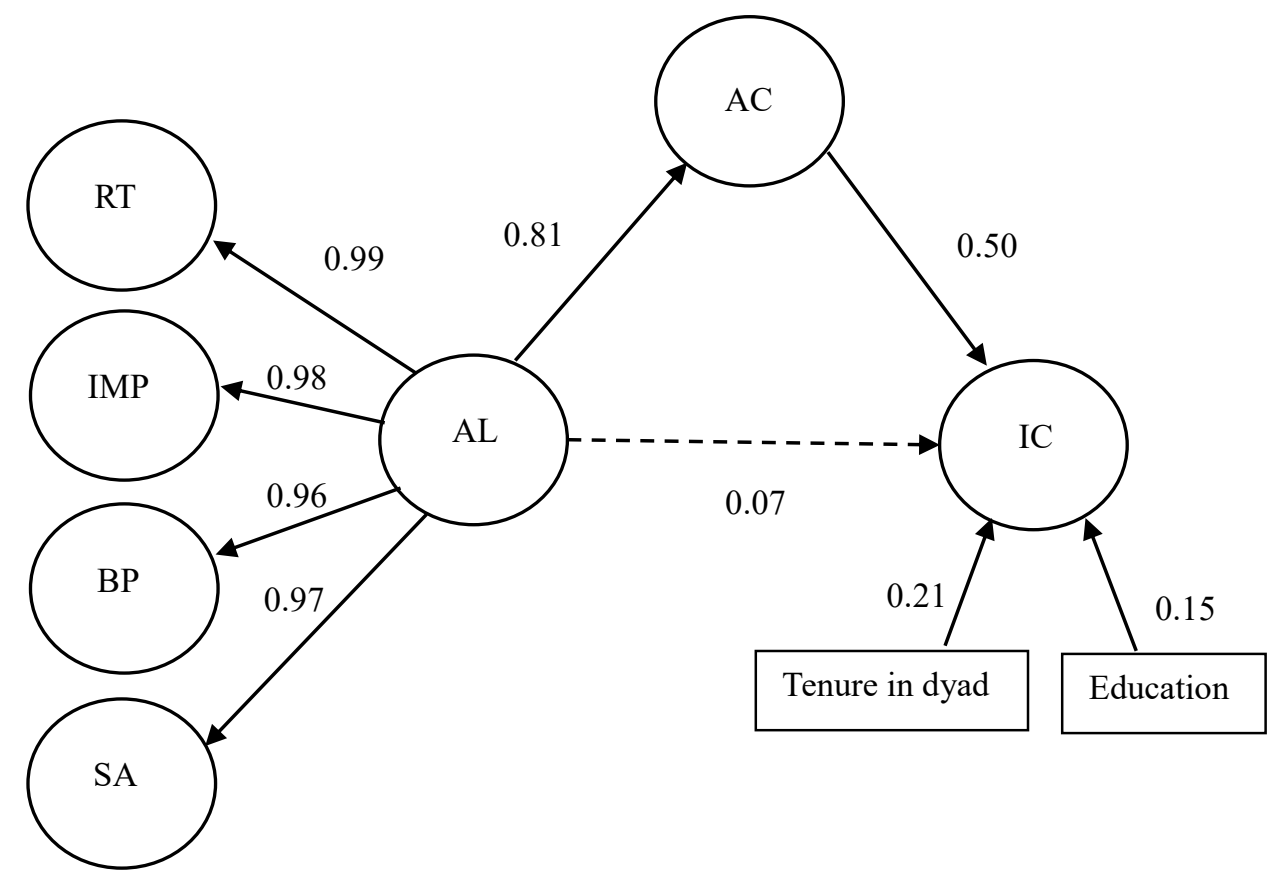

Notes: $\mathrm{RT}=$ relational transparency; IMP $=$ internalized moral perspective; $\mathrm{BP}=$ balanced processing; $\mathrm{SA}=$ self-awareness; $\mathrm{AC}=$ affective commitment; $\mathrm{IC}=$ creativity; $p<0.001$; education $1=6$ years of schooling or less, $2=$ between 7 and 12 years of schooling, $3=$ higher education degree. 